\title{
mLearning- a cost effective initiative for stigma reduction in health care settings
}

\author{
Sree T Sucharitha ${ }^{1 *}$, Janani Rajagopal ${ }^{1}$, Ravi Siriki ${ }^{2}$ \\ From 2nd International Science Symposium on HIV and Infectious Diseases (HIV SCIENCE 2014) \\ Chennai, India. 30 January - 1 February 2014
}

\section{Background}

The total number of people living with HIV (PLHIV) in India estimated to be around 20.9 lakhs in 2011. In Indian hospitals, stigma and discrimination is widespread and has unfavorable impact on treatment outcomes for PLHIV and on battle against HIV epidemic. mLearning is a type of mHealth for educating and increasing the capacity of health care providers. The objective of this study was to assess the effect of mLearning intervention as improvement in knowledge and attitudes in medical undergraduates towards reducing stigma in health care settings.

\section{Methods}

This observational cohort study involved mLearning intervention using the free version of WAY2SMS with thirty short messages (SMS) being sent to thirty medical undergraduates of Tagore Medical College, Chennai during August-October 2013.

\section{Results}

Fear of contagion (33\%) and poor awareness (23\%) among care providers is identified as reasons for stigma. Improved knowledge about definition of stigma as $100 \%$, 97\% for Quality, Quantity of HIV virus and Route of transmission (QQR) determining the risk of HIV transmission, 97\% for identifying scheduling consultancies till last and charging high for PLHIV surgeries as stigma, was seen in mLearning group. Positive attitudinal shift was seen as $100 \%$ participants mentioning they would befriend and would not be ashamed being care providers for PLHIV, 47\% realizing the importance of client informed, voluntary testing for HIV, and $60 \%$ favored informed consent prior to HIV testing.

\footnotetext{
*Correspondence: sucharithat2@gmail.com

'Department of Community Medicine, Tagore Medical College Hospital, Chennai, India

Full list of author information is available at the end of the article
}

\section{Conclusion}

mLearning is a cost effective method of reducing stigma in health care settings by improving knowledge and attitudes of care providers.

\section{Authors' details \\ 'Department of Community Medicine, Tagore Medical College Hospital,} Chennai, India. ${ }^{2}$ Independent Data Consultant, Hyderabad, India.

Published: 27 May 2014

doi:10.1186/1471-2334-14-S3-E46

Cite this article as: Sucharitha et al:: mLearning- a cost effective initiative for stigma reduction in health care settings. BMC Infectious Diseases 2014 14(Suppl 3):E46.
Submit your next manuscript to BioMed Central and take full advantage of:

- Convenient online submission

- Thorough peer review

- No space constraints or color figure charges

- Immediate publication on acceptance

- Inclusion in PubMed, CAS, Scopus and Google Scholar

- Research which is freely available for redistribution
() Biomed Central 